\title{
Property rights in financial transactions
}

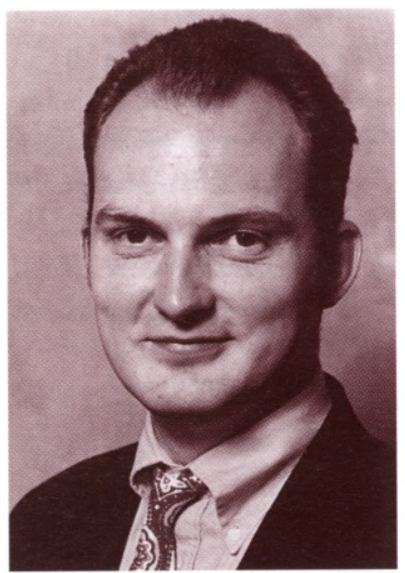

by Alastair Hudson

Alastair Hudson analyses recent House of Lords' decisions in interest rate swaps cases and suggests new ways in which the principles of equity might be applied to solve the problems which arise.

The prevention of systemic failure of financial markets depends in large part on the ability of market participants to have legal recourse to property which has been dealt in and to amounts owed to them. Recent House of Lords' decisions affecting interest rate swaps have attracted a huge academic commentary on their impact on principles of common law, equity and restitution. However their dire impact on financial markets has not been fully appreciated. The courts have assumed that standard market contracts will be completely ineffective for risk management purposes where their economic terms have been held to be void.

There are twơ primary considerations for lawyers creating financial market transactions: the ability to set-off on insolvency of the counterparty and the general efficacy of termination provisions in standard form market contracts. This article considers the growth of recent case-law on this latter area and the impact of recent House of Lords' decisions on the efficacy of financial contracts. Of particular interest is the impact of the swaps cases Westdeutsche Landesbank v Islington [1996] AC 669 and Kleinwort Benson v Glasgow City Council [1997] 4 AER 641 on the contractual and restitutionary effect of void contracts.

It is not suggested here that the decisions on the facts in the swaps cases were wrong. Rather that the principles upon which those decisions were reached have far-reaching implications which would be better avoided. The standard market contracts, considered below, are not adequate to rebut the conclusions of the English courts on their facts. Consequently, it is suggested that there are different principles which ought to be applied by equity, in the context of commercial transactions, to achieve the desirable result of systemic risk management and greater commercial certainty.

\section{AVAILABILITY OF PROPRIETARY REMEDIES}

The central contention of this article is that the result of the majority decisions in the House of Lords in the swaps cases is that it impossible for parties to retain a proprietary interest in property transferred under a commercial contract which is found to be void ab initio. The restatement of the core rules of equity in the speech of Lord Browne-Wilkinson in Westdeutsche Landesbank ${ }_{V}$ Islington created a test that a proprietary claim in constructive trust will only be imposed in circumstances where the defendant has knowledge of the factor which is alleged to impose the office of trustee on him, thus affecting his conscience.

Similarly, a proprietary claim based on resulting trust will only obtain where a purported express trust of an equitable interest has failed to allocate the whole of that interest, or where an equitable interest is created by dint of contribution to the purchase price of property. It is submitted that these principles restrict the potential intervention of equity to such a narrow range of cases that the mutual intentions of parties to commercial contracts will frequently not be enforced by either the rules of common law or of equity.

\section{EFFECT OF VOID CONTRACTS}

The swaps cases concerned two forms of interest rate swap. The first was a deep discount swap in which a lump sum was paid by the bank to the local authority, as well as the usual payment of fixed and floating rate amounts between the parties, calculated by reference to a notional amount of money. The second was a vanilla interest rate swap, providing for payments of fixed and floating amounts of interest, calculated by reference to a notional amount of money. Further to the decision of the House of Lords in Hazell $v$ Hammersmith \& Fulham [1992] 2 AC 1 , these contracts were held to be ultra vires the local authorities and therefore void ab initio.

The issue arose as to the manner in which the banks were entitled to seek recovery of sums paid to the local authorities. The House of Lords was unanimous in holding that neither the lump sum nor any of the interest amounts were to be held on resulting trust. Further, it was unanimous in holding that there would not be a constructive trust imposed over the money, on the basis that the local authorities did not know that the money had been advanced to them under a void transaction and therefore their consciences had not been affected. At most, there was a personal claim in restitution for the amount of 
money transferred under the void agreement, together with simple interest. Lord Goff and Lord Woolf dissented on the availability of compound interest: the former asserting that it ought to have been available on the grounds of justice, the latter asserting that commercial people would expect that it would be made available.

The impact of the decision is that, even though it was accepted that the parties would have expected to receive compound interest on their money in ordinary circumstances and that they had entered into the standard form contracts, parties to financial contracts will not be entitled to proprietary remedies where those agreements are held to be void. Furthermore, it appears from the decisions that any contractual provision which sought to preserve such proprietary rights would itself be void, making the retention of title in such agreements impossible.

\section{A VARIETY OF EQUITABLE TECHNIQUES}

In his article in the Restitution Law Review 1996 at p. 3, Professor Birks refers to there being no real difference between Lords Goff and Browne-Wilkinson in the interpretation of the equitable and restitutionary techniques available in the Islington case. Birks is somewhat dismissive of the extent of any change that is introduced by Lord Browne-Wilkinson. It is possible, however, to see this case as the battleground for three generations of lawyers as to how to consider the position of equitable proprietary remedies. Their approaches to the problem at hand are symptomatic of their generational attitudes. In that context, there were no surprises in the decision nor in the rationales of the decisions.

There are four established approaches to the issues appealed to the House of Lords and considered by the Judicial Committee:

(1) The equity lawyers' approach, a modern trusts vicw, is taken up by Lord Browne-Wilkinson and constitutes the majority decision against an award of compound interest arguing from equitable principle. Contrary to Lord Goff's imprecation that the appeal was not the opportunity to redraw the availability of many of the claims and remedies surrounding equity and restitution, Lord Browne-Wilkinson decided to do so. As a result, the availability of resulting trusts is limited and the doctrine of proprietary interests available further to constructive trusts is redrawn.

(2) The conservative restitution approach is set out in the speech of Lord Goff in which his dissent from the majority is only partial - specifically whether compound interest should be made available as a matter of providing justice. Lord Goff preserves the approach of the classical restitution lawyer in seeking to reverse unjust enrichment caused by the receipt of money, further to a contract void ab initio, by means of the analysis of existing principle.

(3) The radical restitution approach is typified by the work of Professor Birks in seeking to understand the core rationale for effecting restitution for unjust enrichment by subtraction of that enrichment. Much of this academic discussion is considered expressly by their lordships - for the most part the radical approach fares badly before the House of Lords.

(4) A further approach is drawn out at the end of the discussion, to highlight some further issues which would have been open to the courts on the facts before them, also to draw together some common principles from the other approaches which would contribute to greater certainty and justice in commercial and, specifically, financial situations.

\section{THE ARGUMENT FROM RISK}

Financial markets create, manage and exploit risk: frequently at the same time. The role of the lawyer in that context is to be a risk manager. Legal risk management can be achieved in one of two ways. The first is by not entering into the market at all and thus avoiding any risk. It is not proposed to spend any more time on this aspect. The second is by creating contracts which seek to control those risks. Where these contracts are held to be void, the ability of the parties to control their risk portfolio is effectively removed. In unregulated financial markets, the role of commercial and property law is to support prudential and lawful attempts to manage risk.

The impact of ineffective standard market contracts is an increase in systemic risk. This form of risk was highlighted most recently by the collapse of Yamaichi Securities (see Amicus Curiae Issue 3, at p. 31). Systemic risk constitutes the risk that, if one player in the market goes into insolvency and is unable to meet its payment obligation, this will introduce stress into the remainder of the market, creating the further risk that more market users will be forced into a position where they are unable to meet their payment obligations because they have not been paid by the insolvent party. It is this domino effect which is the essence of systemic risk.

\section{RISK OF LOSING LIQUIDITY}

Similarly, where market participants are unable to perform, the risk posed by financial derivatives is a haemorrhaging of liquidity. The notion of liquidity is different from solvency but the economic risks are similar. The aim of a treasury function within a trading company or bank is to provide liquidity without impacting on the solvency of the entity in one way or another. Liquidity means matching obligations with ability to pay. Derivatives markets aim to add to this pool of liquidity as well as to add speculative opportunities. Where payment in full under derivatives contracts is precluded by operation of law there is an increased level of liquidity risk in the market place.

The market place has sought to introduce some protection against this form of total market risk by standardising market practices and standardising legal documentation. The work of the International Swaps and Derivatives Association (ISDA) and the British Bankers' Association (BBA), among others, has been to ensure that termination provisions, payment systems and netting provisions are both standardised and legally effective. This is the source of the derivatives markets' particular concern about the decisions affecting local authorities. At one level, the finding in Hazell that local authorities were not capable of entering into interest rate swaps caused concern with reference to deals with local authorities. However, the greater disquiet has been caused by the manner in which English law has both failed to enforce the terms of those standard market contracts, and the denial of proprietary remedies to market participants.

\section{EQUITY'S RESPONSE}

Lord Browne-Wilkinson held that there could be no retention of any rights in the deep discount payment by the bank because both parties intended that there be an outright transfer of that sum to the authority. The argument for the imposition of a 
resulting trust would be that there was no intention to make a voluntary and outright transfer of the property in circumstances where the contract was found to be void ab initio.

In his 'Restitution and Resulting Trusts' (see Equity and Contemporary Legal Problems, edited by S Goldstein, 1992) Professor Birks suggests, from a restitutionary stand-point, that the role of the resulting trust is primarily restitutionary and that this form of resulting trust should be imposed in cases of mistaken payment or failure of consideration, to reverse unjust enrichment.

At the root of both arguments in favour of the use of the resulting trust is the assertion that the most appropriate response is to hold that the equitable interest in the property in question is to be deemed to have remained with the payer whether that assertion is based on equitable or restitutionary conceptions of justice. However, it is submitted that these suggestions fall into the trap which Lord Browne-Wilkinson has identified: any intention to create a resulting trust is to be rebutted by the intention at the time of the transfer to make an outright transfer. As his lordship held, there is a difficulty with establishing the role of the resulting trustee from the moment of receipt of the property at a time when there was no knowledge of the trusteeship.

\section{EXTENDING CONSTRUCTIVE TRUSTS}

The better approach, not addressed expressly by any of the courts in Islington, would be to extend the common intention constructive trust to commercial situations. Whereas this idea has been restricted to family home trusts, it is an idea which would appear to sit most comfortably in commercial situations. The weakness of the common intention constructive trust, as with all rules governing trusts of co-owned domestic land, is that it rests on a fiction. The fiction is that there has been some agreement between the parties, or some conduct tantamount to an agreement, which ought to form an institutional constructive trust (that is, one founded on the application of principle rather than being a discretionary remedy provided by the court). As a result of this fiction, a constructive trust is imposed to set out the parties' entitlements to the equitable interest in the land. This form of trust is imposed particularly where it is considered inequitable not to do so.

In the context of commercial contracts there is an agreement between the parties. In seeking to establish the equitable title to property passed under a void contract, it is submitted that the court ought to consider the common intention, formed between the parties, as to the title to that property. Given Lord BrowneWilkinson's determination to recognise the intentions of the parties in refuting the possibility of a resulting trust, it would appear appropriate to recognise those intentions when considering the possibility of a constructive trust. This would also appear to address the concerns of Lord Goff and Lord Woolf that justice must be seen to be done and that the confidence of commercial people in the utility of English law must be promoted.

Lord Browne-Wilkinson rejected the possibility of a proprietary interest based on constructive trust on the basis that the English model of constructive trust is institutional in nature, operating in response to the trustee's knowledge of some factor which ought to impact on his conscience sufficiently to warrant the imposition of such a constructive trust. On the facts of Islington it was found that the authority did not have knowledge of the status of the contract until it was declared to be ultra vires by the courts.

However, at that point there is another impact on the authority's conscience: it had already agreed with the bank that it would be bound by the termination provisions in its swap agreement (including calculation of interest and netting of transactions). It is submitted that this prior agreement ought to be sufficient to cause the authority to be bound by those terms of the swap contract with regard to the amount owed under the agreement. Similarly, such common intention as to termination and proprietary rights in assets transferred by arm's length market participants should be enforced by equity through the common intention constructive trust.

\section{NEW CONTRACTS NEEDED}

In the event, the weakness of the market standard contracts for over-the-counter derivatives is that they do not cater sufficiently for retention of title in property. There is clearly an case for ISDA and for the BBA to redraw its standard contracts to take account of this deficiency in counterparty protection. This is particularly so in the case of physically settled transactions and transactions annexed to deep discount payments, where title to the specific property transferred is of greater importance than receipt of its cash equivalent in a designated currency.

The issue which arises is: how can a void contract be given effect in part? More specifically, if the swap contract is held to have been void $a b$ initio, how can the termination provisions or retention of title clauses still be effective? There are two arguments on this basis. First, it is clear from Re Goldcorp [1995] AC 74 that, if a contract is avoided by election of the parties and property transferred under that contract can still be identified, a constructive trust will be imposed over that identifiable property. Therefore, as a result of Islington, there is a difference between the enforceability of a voidable contract and a void contract. (It is accepted that in Islington the property was no longer identifiable because the bank account into which the property had been paid had subsequently been run overdrawn on a number of occasions.)

Secondly, it is submitted that it would be possible to sever the termination provisions from the economic provisions of the swap contract. This contention proceeds on the basis that the latter provisions carry out the interest rate swap which was held to be ultra vires the local authority, whereas the termination provisions provide only a commercially effective means of rescission and contribute to a reduction in systemic risk in the financial markets.

\section{THE SEVERANCE OPTION}

The classic statement of the doctrine of severance is that:

where you cannot sever the illegal from the legal part of a covenant, the contract is altogether void; but, where you can sever them, whether the illegality can be created by statute or by common law, you may reject the bad part and retain the good.' (Pickering v Ilfracombe Railway (1868) LR 3 CP 235)

The decision of Megarry J in Spector $v$ Ageda [1973] CH 30 held that the whole of the contract must be considered to be void even where a part only of the agreement had been found to be illegal by operation of statute. The policy identified in this decision was to prevent parties to illegal contracts from putting themselves into further harm by enforcing other contracts. 
Similarly, in Esso Petroleum v Harper's Garage (Stourport) Ltd [1968] AC 269 it was held that, where covenants in a contract are so closely connected that they can be deemed to stand or fall together, the whole contract will fail even though some sections may appear to be severable.

The risk management features of standard market financial documents introduce greater certainty and lessen the cash amounts required to be paid between market participants. Therefore the identified policy of precluding the parties from entering into further damaging transactions does not apply in the context of a provision, such as a netting clause on termination, which reduces the net amount of the parties' exposure to one another. The validity of an instrument need not be compromised because some element of it is held to be unenforceable (see Gaskell v King (1809) 11 East 165).

The doctrine of severance might also apply with reference to the distinction between executed and non-executed transactions. It could be submitted that, where the parties have acted consensually and without any other unjust factor such as fraud or undue influence, there is no injustice in requiring the parties to observe their agreement.

There is a further issue as to the efficacy of collateral 'credit support agreements' which cannot be considered here due to lack of space. However it appears that ISDA's current strategy with regard to credit support documentation will not be sustainable in the light of the decisions in Islington and Kleinwort Benson.

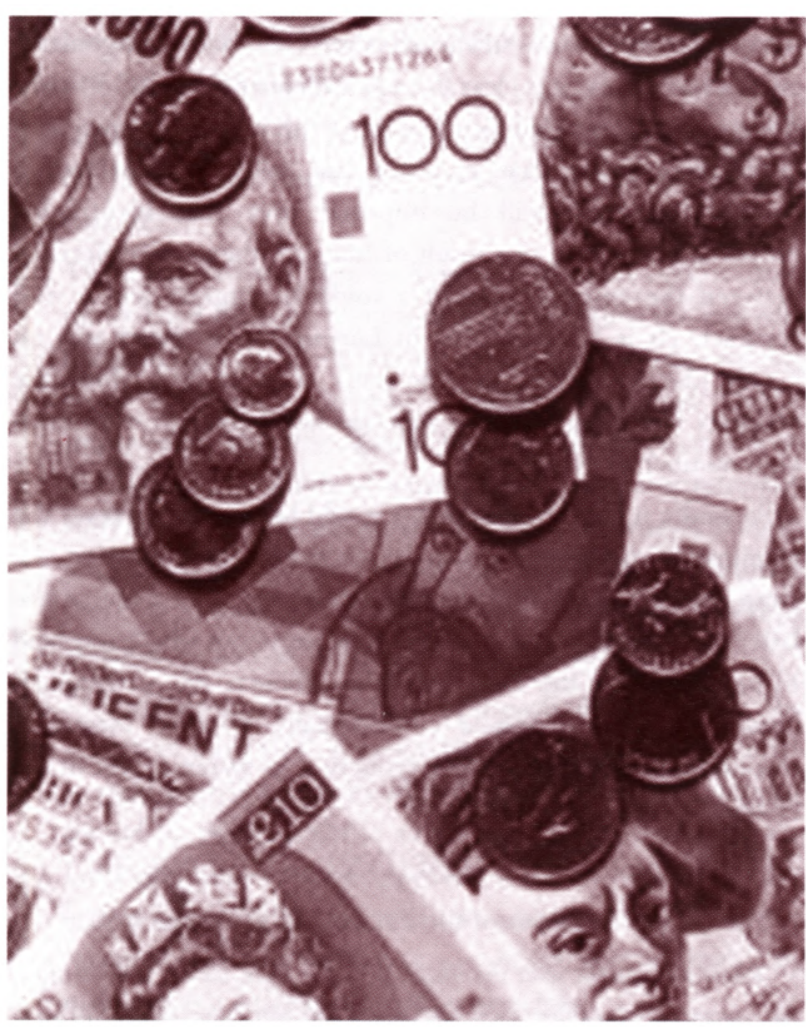

In the Court of Appeal in Westdeutsche Landesbank v Islington [1994] 4 AER 890, Dillon LJ held:

'I do not see why a similar process of severance should not be applied where what has happened, in a purely financial matter, is that there has been a payment of money one way and a payment of smaller sums of money the other way. The effect of severance is that there has been a total failure of consideration in respect of the balance of the money which has not come back.'
One important issue arising in this context is why severance had not been similarly available with reference to the Sandwell litigation, which was initially joined with Islington, where some of the contracts had been performed.

The further issue is whether some of the payments made between the parties could be treated as settled (thus supporting a mutual debts analysis) or whether they are to be required as part of a single (executory) contract which had not been fully performed until the final payment had been made. This topic was discussed in my earlier article in the November 1997 issue of Amicus Curiae (Issue 2, at p. 27).

\section{CONCLUSION}

In considering commercial situations, the appropriate rules of equity should either allow for an equitable proprietary remedy to be available to a party where the contractual agreement has allocated title to the property transferred under the transaction, or allow an equitable proprietary remedy according with the common intention of the parties as set out in an agreement between them. It is similarly arguable that such a remedy ought to be available where there was some undue influence in the creation of the financial product, or where either party was caused to be unjustly enriched at the expense of the other party, or where rescission is the appropriate remedy under a physically settled transaction.

It is suggested that the usual defences of change of position and passing on would still obtain. Similarly public policy would constitute an exception in such circumstances.

A remedy by means of equitable compensation or by imposition of personal liability under constructive trust should be made available in cases of:

(1) reckless risk-taking;

(2) where the product was unsuitable;

(3) if rescission is the appropriate remedy under a cash-settled transaction;

(4) if the risk taken, or the context in which the risk was taken, contravened some principle of public policy or of statute or of some other mandatory rule of law or equity.

What is not supportable is the dismay in the commercial community outside the UK which relies on English law. Lord Woolf referred to the need for a modern test in financial transactions based on foreseeability of loss. As Lord BrowneWilkinson found in Target Holdings [1996] 1 AC 421, there is a need to break from the application of traditional rules to commercial situations and consider the commercial context for equity.

In Royal Brunei Airlines v Tan [1995] 2 AC 378, Lord Nicholls accepted the need to recognise inappropriate risk-taking by a fiduciary as a ground for a claim in equity. In the context of financial contracts, equity must accept the need to account for risk and suitability of product. As a corollary to this, it must enforce the common intention of the parties as to the termination of financial contracts.

Alastair Hudson

Queen Mary and Westfield College 